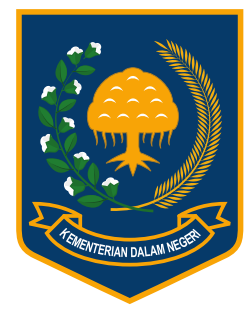

Jurnal Bina Praja 8 (1) (2016): 109-119

Jurnal Bina Praja

e-ISSN: 2503-3360 | p-ISSN: 2085-4323

Accreditation Number

735/AU2/P2MI-LIPI/04/2016

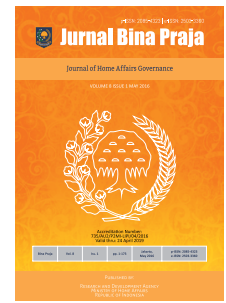

http://jurnal.kemendagri.go.id/index.php/jbp/index

\title{
SOLVING LOCAL VIOLENCE BY COSMOPOLITAN DEMOCRACY APPROACH
}

\author{
Muhammad Luthfil Hakim ${ }^{1,}{ }^{*}$, Nasrun Annahar ${ }^{2}$ \\ ${ }^{1}$ Pesantren Studies Center of Universitas Brawijaya \\ Perum Dwiga Regency A3 No. 12, Malang City, Indonesia \\ ${ }^{2}$ Avemedia Research \\ Perum Dwiga Regency A3 No. 12, Malang City, Indonesia
}

Received: 2 February 2016; Accepted: 23 April 2016; Published online: 31 May 2016

\begin{abstract}
The implementation of democracy intensified since the fall of the new order era has some failures. One of the factors is violence phenomena still continue in the region. This study aims to discuss the violence in the region by presenting cosmopolitan democracy as a new design of more humane democracy. In addition, this research method uses library research, because library research can understand the problem in-depth to find the pattern and recommendation from the violence problems which happens in Indonesia. This study uses Hannah Arendt observations on the phenomenon of violence. In addition, the concept of cosmopolitan democracy is referred from Daniele Archibugi, David Held, and Ulrich Beck is presented as a draft of new democracy direction which is more inclusive and humane. The result of this study discloses that the occurrence of incidence is triggered by failed implementation of the democratic system in Indonesia.
\end{abstract}

Keywords: cosmopolitan democracy, violence, local government

\section{INTRODUCTION}

Cosmopolitan democracy is about to give a variation form of democracy that is more likely to ensure peace and human rights. This form is so that people could be aware that they are not just part of their identity, but also part of the world.

Today the discussion of cosmopolitan democracy burst and meet the scientific discussion forums around the world. This happens because a variety of existing democratic models never resolve the problems of conflict and violence. The implementation of democracy, in fact, go hand in hand with the emergence of various cases of violence.

Although the democratic system has been rolled out and aggressively campaigned since 2004, violence between religious, cultural, ethnic, and inter interests, keeps on plaguing political and social conditions of the region. This can be evidenced by the data of SETARA Institute (2009) which states that there are at least 200 violations of freedom of religion/belief which contain 291 types of actions at the regional level (Adian, 2010: 12). Furthermore, violence between religious groups occurred in 2015 in Tolikara.

On the other hand, since the reform era in 1998 , state violence is expected to be minimized. While in fact, there are a lot of violence perpetrated by groups/actors/institutions of the state (government) to the community. Evictions of residents of Kampung Pulo, Urut Sewu Farmers, and Kendeng Rembang Farmers are clear examples of this phenomenon (Monitorday, 2015, Ardianto, 2015 and Aprianto, 2014). This proves that the state (Central Government or Local Government also) have not been able to understand the purpose of the presence of democracy for the people.

Actually, the existence of local government is able to absorb the aspirations of the people. The aspiration then ideally can provide policies and services oriented to the welfare of the people. In addition, critical awareness of society and local government towards the actualization of democracy has not happened yet to fill the dynamics of public space. Therefore, the phenomenon of violence still occur in Indonesia despite the constitutionally democratic system changes are frequently changed.

Democracy as a system that ensures the

\footnotetext{
* Corresponding Author

Phone : +6285258241607

Email : luthfil@nalarkritis.org
} 
participation of the people has been expected to overcome the various problems mentioned above. The expectation also makes various countries interested in making democracy as an ideal system for the administration. Archibugi (2008: 32) found an increasing number of adherents of democratic countries from 1945 to 2005. Accordingly, Held (1995: 3) also confirms that democracy becomes one form of governance that has been won in competition with other forms of governance.

The exposure of data by Archibugi and the statement by Held have proved that democracy is a system that is considered able to bring people with dreams of prosperity. However, the implementation of democracy in Indonesia is still limited to procedural and not yet able to provide significant benefits to the community. Santoso (2014: 400) added that "Democracy in Indonesia is not an ethical commitment to citizens. Democracy is still the skin or outer appearance of politics in Indonesia."

Arendt, in Haryatmoko (2014: 177) viewed that one of the prerequisites of minimizing violence is through action and speech as a political action undertaken in filling public space. Therefore, the concept of cosmopolitan democracy is considered important to be discussed as one of the alternative variants that are expected to parse the violence that occurred in various regions in Indonesia. This statement is confirmed by Mary Kaldor (2000: 6), that the cosmopolitan democracy becomes possible to make the phenomenon of power without violence.

Out of urgency for discussion on democracy and violence, this study will answer the question: "How to overcome the violence in the regions in the view of cosmopolitan democracy?". Thus, this study aims to discuss violence in the region by presenting cosmopolitan democracy as a new more humane democracy design. This study will also use literature study research method that is considered able to explain the problem in depth.

Several previous studies become the reference of the author for this study to confirm the position of this study. One is the conducted by Mary Kaldor (2000). In her journal, entitled Cosmopolitanism and Organised Violence, Mary explained cosmopolitanism approach could be the solution of various global interests of war, or as she called it (New Wars). Mary used a qualitative method that can explain the focus of her research.

Based on the study by Kaldor, and referring to the arguments of Archibugi, Held, and Beck, the author gets the sense that the cosmopolitan democracy is a concept of the development of the basic principles of democracy. Basically, this concept develops the meaning of people in a greater sense of the greater meaning of democracy, namely by abolishing the limits of the people on the issue of ethnic, regional, or state. In the end, smelting above restrictions is intended for solving global problems based on an issue.

In addition, the book entitled "Rembang Melawan" (Ardianto, et al., 2015), which is an anthology of the work of the observers of mine dispute, could be a reference to the fact that violence against Kendeng residents. In the book, there is a research that revealed the presence of violence there, one of which is a work of Ming-Ming Lukiarti entitled "the struggle of Female Farmers in Rembang Against Corporate Mine." There is also in the book a study by Hendra Try Adianto entitled "Death Sense of Empathy As Human." This book is important as a reference for this study because it can describe the phenomenon of violence in Kendeng area.

With reference to previous studies above, this study is positioned to update the study of cosmopolitan democracy by viewing violence as one of the problems in a democracy. Therefore, this study has critical importance to renew the study of democracy and update the analysis of violence in the regions.

\section{METHOD}

This study uses library research. The reason for using this method is because the problem examined is unclear or there has not been much study was done, holistic, complex, dynamic, and full of meaning from a variety of written sources. Another reason that is more important is that the study of literature is able to understand the problem in depth in order to find patterns and recommendations on issues of violence that occurred in Indonesia.

Library study is research conducted only on the basis of written works, including research results, both that have been or have not been well publicized. The method of data collection in this method is not obtained by plunging into the field. In other words, library research is a method for searching, collecting, and analyzing the data source to be processed and presented in the form of the research report. According to Mardalis (2004), the study of literature one of which aims to collect data and information with the help of a variety of materials such as books, magazines, documents, records, historical tales, and others.

The literature data source is all books that are relevant to the theme or the issues of violence and cosmopolitan democracy. Sources of data in this study are divided into two, namely primary and secondary sources. Primary source means that it is originated from all written material of the first source. While secondary source comes from all the written material which is derived indirectly from the first source that addresses the issue studied.

Documentative data in the form of this literature research is in the form of facts stated by sentences. Therefore, the discussion and analysis 
are done with objective interpretations in the form of in-depth study on the problem of violence and the prospect of cosmopolitan democracy as a way out. The research data is described with content analysis and descriptive analysis.

Indeed, the study of literature is not limited to the method of collecting data, but need other aspects such as the formulation of the problem, the theoretical basis/literature review, data analysis, and policy conclusions in order to find wholeness in the study. The study of this type contain some ideas or theories that are mutually relating rigorously and as well as supported by data from literature sources.

In the discussion, literature study is conducted on various cases of violence which then elaborated with the literature or literature about cosmopolitan democracy. Various cases of violence are scrutinized within the framework of the theory of violence and cosmopolitan democracy to seek common ground resolution.

The conclusion of this study is obtained by collecting data/information from various published sources, as disclosed previously, then processed and presented in a new way to gain a new perspective for a new benefit too.

In this research, a literature search is more than just to serve the functions of research framework preparatory, sharpen methodology or deepen theoretical studies. Library research can simultaneously utilize library resources to obtain data on research without doing field research. Therefore, this study follows the process as suggested by Correa and Owens (2010, 196-205) with the following process: (1) Decide on a topic, (2) Change the topic in the scientific argument, (3) Look for supporting information, (4) Reinforce the focus, (5) Organize the reading material, (6) Finding the necessary materials, (7) Reorganize materials and make a note of the study (it is the core process), (8) Review and enrich more reading material, (9) Reorganize again the material/notes and then started writing, (10) formulate a recommendation.

\section{RESULT AND DISCUSSION}

\section{A. The Failure of Indonesian Democracy}

Chapter of discussion in this study will present analytically that the failure of democratic is in the form of violence in the regions. The author took four examples of case studies that are analyzed through a conceptual overview of Hannah Arendt on the banality of evil. After outlining the violence, the discussion will be continued by presenting cosmopolitan democracy as an option of renewal of democracy in Indonesia. Discussion of research seeks to answer the formulation of the problem: how to solve the violence in the regions in the view of cosmopolitan democracy? Thus, this research can aim to address violence in the regions by presenting cosmopolitan democracy as a new more humane democracy design.

Communal violence in various regions in Indonesia is called by Adian (2010: 13) as closely related to the fault of choice of post-Reformation political ideology. The euphoria of reform gives the freedom of expression of various communities. This then gives high enough space to conflict and violence in various regions. The role of the state weakened. On the other hand, the civil power in the name of democracy is increasingly bold and free to act.

After the collapse of the New Order, Indonesia experienced ambivalence on the meaning of democracy. The main constraint on the meaning of democracy is that democracy is only and always linked to the state. For example, Indonesia is proud as a democratic state because it has made the direct election. Political indicators seemed to be the primary domain in building democracy. Either scientists, statesmen, politicians and the public never thought that that democracy is not just a matter of governance and politics.

According to Karib (2011), the ambivalence of the meaning of democracy is because: First, Indonesia is only seen as a democratic state. Indonesia as a public entity has always ruled out, this view of "democratic society" is always left out of the discussions. The success of democracy in the mainstream view is only measured by the success of the elections. Democracy only seen limited to the procedure or the hardware, but forget the software of democracy, namely values of democracy such as pluralism and tolerance.

This fallacy of thinking is more evident when direct local elections are considered democratic (meaning hardware), forgetting the values of harmony and pluralism (meaning the software). The tip of this is the occurrence of cases of violence between supporters of prospective head regions. The lack of awareness of the software ultimately makes one of the supporters of the defeated candidate rage and use violence in response to the election that was considered democratic earlier.

Second, forgetting the software in a democracy means hindering the process of social change. Giving priority to procedural democracy in the discussions also means more concerned with political transactions at the level of power, in parliament rooms and party lines lobbies.

Various groups or communities are then reluctant in a socio-cultural manner to change their solidarity to the level of citizens because the state as a political instrument and facilitator with its efforts to improve the life of citizens has failed. Individuals in the community do not feel justice in the economy, politics, and culture. 
Table 1.

Data of Violent Cases in the Regions

\begin{tabular}{|c|c|c|}
\hline Location and Time & Actors of Violence & Remarks \\
\hline $\begin{array}{l}\text { Rembang District, } \\
\text { Central Java, on } 16 \\
\text { June } 2014\end{array}$ & $\begin{array}{l}\text { Government } \\
\text { through TNI and } \\
\text { Polri apparatus }\end{array}$ & $\begin{array}{l}\text { Kendeng residents } \\
\text { protesting against } \\
\text { the construction } \\
\text { of the cement } \\
\text { plant was forcibly } \\
\text { disbanded and } \\
\text { in sweeping by } \\
\text { apparatus (TNI and } \\
\text { Polri). Some moth- } \\
\text { ers were strangled } \\
\text { and thrown into } \\
\text { the bush. Seven } \\
\text { residents had been } \\
\text { secured, although } \\
\text { later released. }\end{array}$ \\
\hline $\begin{array}{l}\text { Urut Sewu, Kebu- } \\
\text { men, Central Jawa, } \\
\text { on } 22 \text { August } 2015\end{array}$ & $\begin{array}{l}\text { Government } \\
\text { through TNI appa- } \\
\text { ratus }\end{array}$ & $\begin{array}{l}\text { Urut Sewu } \\
\text { residents felt } \\
\text { unfairness on the } \\
\text { arbitrariness of } \\
\text { fencing their land } \\
\text { by the military. } \\
\text { Residents take } \\
\text { action to reject the } \\
\text { fencing. Casualties } \\
\text { on the part of citi- } \\
\text { zens. Four people } \\
\text { were seriously } \\
\text { wounded, and } \\
\text { dozens of minor } \\
\text { injuries. }\end{array}$ \\
\hline $\begin{array}{l}\text { Kampung Pulo, DKI } \\
\text { Jakarta, } 20 \text { August } \\
2015\end{array}$ & $\begin{array}{l}\text { Government } \\
\text { through Joint } \\
\text { apparatus (Police, } \\
\text { Satpol PP, and TNI) }\end{array}$ & $\begin{array}{l}\text { Citizens took } \\
\text { action of rejection } \\
\text { to be evicted and } \\
\text { were engaged } \\
\text { in the friction } \\
\text { with the joint } \\
\text { personnel, result- } \\
\text { ing in dozens of } \\
\text { people injured, } 27 \\
\text { arrested. }\end{array}$ \\
\hline $\begin{array}{l}\text { Tolikara, Papua, } 17 \\
\text { July } 2015\end{array}$ & $\begin{array}{l}\text { GIDI group mem- } \\
\text { bers and the Police }\end{array}$ & $\begin{array}{l}\text { GIDI group made } \\
\text { attacks on Mus- } \\
\text { lims who were } \\
\text { conducting Eid } \\
\text { prayer. As a result, } \\
\text { some stalls burned } \\
\text { by GIDI members, } \\
\text { including the } \\
\text { mosque for Eid } \\
\text { prayer. } 12 \text { casu- } \\
\text { alties were shot } \\
\text { and one died from } \\
\text { GIDI members, as } \\
\text { a result of police } \\
\text { shot. }\end{array}$ \\
\hline
\end{tabular}

Sources: Processed from Various Sources
Ideally, according to Carothers (in Winarno, 2008: 127), democracy should be free from violence. However, democracy proceduralism in Indonesia has clearly failed to minimize levels of violence. In the sub-section below, the author will prove analytically that violence is still plurally found in Indonesia.

\section{B. Violence in the Regions}

The fact of violence in the region occurred horribly, fatalities fell without optimal completion. Below is a table that describes the examples of violent incidents in the regions collected from various media within the last two years:

Four of the above cases are taken as the example of violence in the regions. According to Wahid Institute (2014: 21) throughout 2014 occurred 158 events and 187 violations of religious freedom. As a critical reflection, the question then arises, why the violence could happen?

Arendt's framework is used to explain the causes of the violence. It also used to be able to strengthen the argument of cosmopolitan democracy.

Arendt provides an analysis of the violence resulting from the inability to think of the victims and in the absence of imagination of perpetrator (Wattimena, 2015). For Arendt, the intelligent man also has the potential to commit a crime when he was not thinking. Eichmann, one of the perpetrators which should be responsible for the death of Jews in the Concentration Camp, described by Arendt in his report as a role model in the family, have positive ideas and living just as a normal human (Arendt, 2012). This sort of thing as Arendt called the banality of evil. That people are not conscious of themselves who committed the crime because he was just following the rules (Wattimena, 2015).

Assessing of violence that occurred in various areas using the framework of Arendt, then the perpetrator of this violence are not aware that he committed crimes against those who are victims. Such as military members which perform an action using violence against citizens in Urut Sewu. Members of the military are unconsciously moved to do expulsion accompanied by violence, by assumption because they are part of the commander command.

The violence occurred not because of military members do not have the intelligence, but they, as actors, do not understand that it is an act of crime that causes physical casualties. As well as the groups of people which committed arson in a mosque in Tolikara, they assume that the fault of Muslims who turned loudspeakers on Eid alFitr has disrupted religious activities. To these problems, (the group that committed arson) ignited to violence by throwing stones and damaging 
religious infrastructure in an effort to raise the deterrent effect against Muslims. They do not know that what they do constitute a form of violence that is traumatizing for Muslims.

Similarly in Jakarta, the apparatus in the field do not think that the execution of their duties in the field is an act of violence. In Jakarta, Jakarta Governor decided to relocate the residents of Kampung Pulo in order to minimize flooding in Jakarta. It becomes the legitimacy of the authorities to immediately move the residents of Kampung Pulo. They urged by means of repressive and it caused casualties. Officers who are moving, on the one hand, is the right thing to do because they follow the instructions of their superiors. But on the other hand, their inability to think causes violence that allows residents to do the same.

Almost similar as is the case in Kampung Pulo, some time since February 2016, the Jakarta administration returned in doing evictions in the area Kalijodo. Eviction, this time, though without casualties physically, but, as reported by tempo. com involving at least 800 apparatus to repress the people who will be evicted. It makes violence remains solid position to haunt the community than more harmonious dialogical aspect.

In Rembang, the case of violence involving officials and the community is unfortunate. Most of the victims were women farmers that are protesting against the cement plant. They forcibly disbanded by the authorities, through the action of beatings and physical push. Just as actors in the three cases above, the apparatus do not have the mindset that violence can not solve the problems away.

Of the various forms of violence, Arendt then provided an analysis of human action. According to him, there are two forms of human action, namely irreversible and unpredictable. Irreversible is a form of human action that can not restore to the zero point (Haryatmoko, 2004: 96-98). For example, after the vandalism of religious facilities in Tolikara Muslims, the perpetrators through their representatives declared themselves to be reconciled with Muslims. On the other hand, for Muslims, such events cannot be eliminated in the memory, although Muslims have given forgiveness for what has happened.

Unpredictable is the action taken by human that run without prediction. Every action is potential to give rise to autonomization that is out of the actor's control (Haryatmoko, 2004). Violence in Kampung Pulo is the right illustration in this case. The residents of Kampung Pulo as victims will feel that the violence committed by the police and other authorities must be met with violent efforts anyway. the eviction parties do not realize that their violence had caused the potential spread of violence too on the part of the victim. Arendt in another language also stated that violence is a silent communication par Excellence, or "violence can bring other violence" (Haryatmoko, 2004: 176).

As an effort to ensure violence does not just show up, Arendt expects the presence of actions and speech that are conducted by individuals and society as a political action in the public sphere. The action is part of the vita active (active life) that is coupled with two other instruments, namely work and the works.

Through political action, people can understand the meaning of plurality. An awareness of the-the presence of other people in life (Haryatmoko, 2004: 175). If the plurality has given a present in the human mind, speech and action are taken in public space can reveal the man's identity. Simply put, people can be awakened to the need to appreciate the presence of others. Aware that there is otherness between human beings with one another.

Violence in the region is predicted to continue to happen if the government and democracy actors are unable to understand the context of the values of the democratic system. Jack Snyder, in his book "From Voting to Bloodshed" originally entitled "From Voting to Violence", stated that he agreed with the terms of ideal democracy, namely: the presence of certain level of prosperity, educated citizens, strong support from elites, growing guarantee on the rule of law and the rights of citizens (2000: 367). These terms of democracy can not be separated from research on violent conflict in developing countries. In fact, developing countries that are undergoing a phase of democratization as Indonesia continues to experience symptoms of violence in the country.

In Indonesia, in accordance with the terms of ideal democracy according to Snyder, still have a low level of society prosperity. The data from BPS stated that at least a number of poor people in Indonesia in March 2016 amounted to 28.59 million people (11.22 percent), increased by 0.86 million compared with the condition of September 2014 of 27.73 million people (10, 96 percent) (CBS, 2015). This condition is also exacerbated by the number of human rights violations in Indonesia. The Commission for Missing Persons and Victims of Violence (Kontras) said that throughout the month of January to November 2013, there have been 709 cases of alleged human rights violations by police officers (Tempo, 2013). These data also reinforced by data on violence as has been mentioned above. The high the case of human rights violations and the number of poor people remains high, proving that Indonesia is still unable to apply ideal conditions of democracy according to Snyder.

Meanwhile, the situation today is known to be more complex as globalization causes a rapid change of era. If the violence in the regions continues, while globalization also happens rapidly, then it can not be denied that primordialism and ethnocentrism 
return again as a virus to socio-political reality in Indonesia. This is also confirmed by Syeirazi (2003: 29), he stated that globalization can be postulated as the driving force of violence. The violence that occurred, further by Syeirazi, can be in the form of many faces, such as religious, communal, and political.

Cosmopolitan democracy provides an overview of the reality that occurs in the people (around the world) to reflect again the meaning of identity and universality. This democracy is presented in the middle of the deadlock of democracy and the adverse effects of globalization that continue to spread. Therefore, the analysis review of Hannah Arendt's thought on political action in the vita activa can be in line with cosmopolitan democracy that is present to outline the issues in society in the era of globalization.

\section{Cosmopolitan Democracy As a Way}

Perhaps cosmopolitan democracy is rarely heard than other democracy terms. Thought on cosmopolitan democracy is heavily influenced by Ulrich Beck, Archibugi, and Held. All three were inspired to establish governance for all people in the world, by going beyond state borders. They agreed that the country as a symbol of the capital has failed to provide a guarantee towards the guarantee of human rights and economic prosperity for its citizens. However, they did not necessarily agree with the establishment of the world with one leader.

Linguistically, cosmopolitan comes from the Greek, in which cosmos means the universe/world. While polite means citizens. By this then according to the rules of the language, cosmopolitan is a citizen of the world (Held, 2015: 153).

The term cosmopolitan was popularized by Diagones (Greek philosopher) who stated "I am a citizen of the world," when asked about where he came from (Juvenal, 2015). In this modern era, Beck (2006: 3) stated that cosmopolitan is the view of the sense of the absence of boundaries. The boundaries, in this case, are geographical boundaries, barriers of ethnicity, culture, religion or identity.

In a differentrealm, Jonathan Kuyper (2012: 29) stated that cosmopolitanism is: "Cosmopolitanism, at its core, is concerned with the moral (and hence political) equality of all persons". The doctrine of cosmopolitan reflects that humans are basically representing the community, without the barriers of nationality (Habibullah, 2012: 115). Even so, cosmopolitanism is not to abolish those limits. Cosmopolitan easily be understood as a lack of view of where and from whom human beings are born, and to urge the uphold of the dignity of humanity without exception.

Cosmopolitan democracy according to the Oxford Dictionary (2015) is defined as a political system where democracy is implemented on a global scale, either directly or through a representative. Archibugi stated that there are two rational choices why cosmopolitan democracy can be an alternative as a form of democracy that can overcome violence: First, democracy is better to meet the demands of the world's population than any other form of government. As is known, one of the demands of the world is a global well-being, which also includes the peace of the world. During this time, democracy almost loses its direction after in the application is still found many economic disparities, poverty of population, and gang violence. This problem does not then blame that the democratic system has failed, and then reverse the monarchy or oligarchy system. Instead, democracy as a system is supposed to be improved by bringing forward the appointment of the issues that occur in the area. Therefore, for Archibugi, there is nothing wrong if cosmopolitan democracy is actualized in order to address global issues and challenges.

Second, the success of democracy until now is not yet at a stage to resolve the problem of inclusion. The success of democracy is precise to reach only the scope of a few countries, has not been able to go beyond the state boundaries. In general, there is no doubt that democracy in practice has positive benefits. This can be seen in developed countries, such as America, Germany, and England. Most developed countries have to implement democracy as a way to organize society. Unfortunately, this goodness is only in developed countries. In developing countries such as Indonesia, democracy has not been able to have an important impact on the reduction of violence and increasing economic growth. This proves that there is an absence of global interconnection between countries with one another in the theme of solidarity for mutual support. In fact over the years, relations between countries are only used as one of the efforts merely to make capital profits. As a result, these relations actually cause conflicts between states (Archibugi, 2008: 87).

Reviewing the overview of cosmopolitan democracy, then the relations between violence related to the government and groups that use identity actually can be elaborated. The trick is through the awareness to connect globally, transcending geographical boundaries or identity, with the aim to take the universality of each of the issues raised in the region.

Archibugi (2008: 88) added at least five priorities in the preparation of democracy by bringing in the review of cosmopolitan democracy:

1. Control over the use of force. control of violence, either inside or outside the country. The use of force can only be used as the last option with careful consideration to protect the democratic 
system that goes against the perpetrators of terror. This priority wants a condition for the anti-violence. In Indonesia, violence seems to be unimportant issues. This is evidenced by the argument that democratic system changes only lead to the issue of elections. In addition, changes in the center of the democratic system or its application in the area only based on political interests alone. Therefore, it becomes important to be considered to improve the quality of humanist democracy.

2. Acceptance of cultural diversity. It is an acceptance of cultural diversity in the world. No matter what, identity can not be separated from human beings, but human beings must also be able to recognize and respect their different identities with other human beings. Through this priority, the government is expected to actualize services and public policy that care about diversity. During this time, the public service only formally executed without the will to provide accessibility to the public. Thus, minorities like the case in Tolikara do not get a guarantee of quality public services. The impact of sectarian violence occurs without the government efforts to protect minorities preventively. Public service accessibility technically should also be inclusive of marginalized people, such as disabled people. At least, it has become a common view that the public service in Indonesia is not friendly to people with disabilities.

3. Strengthening of the self-determination of peoples. This is an effort the active participation of the entire community as measures to minimize their dominance. People should also be aware that their existence will be considered through an active political participation. Political participation is not only understood through participation in electoral terms but also How the will of the community contribute to control the running of the government and propose policies. Participation is in line with the idea of Arendt about the vita activa, which encourages people to take action and speech in order to fulfill public space. With their participation, at least the formulation of policies would better accommodate the interests, so violence becomes easy to be minimized.

4. Monitoring of internal affairs. This is an attempt to access internal connection or, in concrete, relations that allow authoritarianism. One weak point of democracy is still a gap on the leaders to abuse of power. This problem arises when society does not actively control the course of social and political systems in the region. As with cases of violence in the region, actually, regional leaders know that violence is a phenomenon that should be minimized. However, poor public awareness makes the ruling authorities obscure the consciousness for the interest to perpetuate powers.

5. Participatory management of global problems. This is an effort to the participatory management of global problems. Problems that occur in the lower layers of any society raised and set to be solved together. The aim is to achieve political equality and intractable global problems. In this principle, the interconnection between the groups with one another is needed by fusing regional boundaries. One aim is to raise the potential of the advantages of a group. By discussing the advantages and potential across from each region, is expected the attempt to forge a new value. The logic is that when a country has an advantage in the conflict resolution process, while in Indonesia the conflict always leads to violence. Indonesia could learn from other countries to determine how to reduce conflicts without having to go through violence.

Cosmopolitan democracy efforts in these five priorities are to stress the efforts so that violence does not occur and could only be done when there is a terror to situations that threaten the democratic system. To make violence minimized, people are required to have an active participation and oversight of power or environment.

Lastly, it is an attempt to resolve cases of shared violence beyond the boundaries of the region. The process of identifying issues management in each region which have the potential conflicts should be done by finding a common ground of potential conflict. For example, the similarity of the problem would be a lack of understanding of the plurality of embryonic life so that it gives rise to violence.

Five priorities to build a democracy based on cosmopolitanism was later confirmed by Held. Held, through his research, provides an analysis of the form of the principles of the cosmopolitan. He explained a principle that is emphasized so that there will be the absence of violence in the application of democracy. He moved from a relationship between a democratic state, which in fact mutually wreak violence, such as the war in Afghanistan, Syria, and Iraq. We can see that the democratic countries contribute to violence in the interest of their country, even though often their pretext is to bring peace.

More specifically, Held (2005: 154-157) stated the eight principles of cosmopolitanism to support the cosmopolitan democracy, namely:

1. Equal worth and dignity: The emphasis that all human beings have self-esteem / honor and dignity that must be respected. That is, in this principle, of any race, color and language, 
all men must earn the respect in a fair, alike, and equal. manner The issue of violence in the regions, as the case study above, an example of the absence of a sense of perpetrator to respect the dignity of others.

2. Active agency: that all human beings have the awareness of existence itself, so that man is able to reflect on yourself. Through this, then the man will make him aware that no man is superior, the man who knows more about life. This principle also explains that no one group of men is entitled to decide that they are the most correct. This idea into line with the ideals Arendt, as described in the previous chapter. That through the mindset in the form of internalization of self, the subject will feel conscious that other people also have selfesteem that must be respected.

3. Personal responsibility: namely that people should be aware and responsible for their actions. This principle is a critical consequence of the existence of freedom in a democracy. Freedom of the individual and groups might be the right to speak, political choice, and action. If this freedom is without limits, then it would clash between the freedom of individuals to one another. Therefore, the attitude of responsibility becomes an important limitation of any freedom of the individual and the group. The case studies that is exemplified above is evidence of the absence of government responsibility in every action. Evidently, the government is not responsible morally and materially to the victims of violence. Instead, the government always gives a negative presumption against the victims in cases such as evictions.

4. Consent: Human life is interrelated to one another basically can have the same rights in the global discussion to determine the direction of civilization. Simply put, the approval of which discuss equal rights and equality of moral values between groups (interconnection) can be used as a shared commitment. The fate that humans are a creature that equally have sense and mutual need, be a potential for the existence of the agreements reached and then carried out together. Through this spirit, at least every policy is not only as a doctrine from top to bottom, but it may be binding through participatory consciousness.

5. Collective decision-making about public matters through voting procedures: Due to the public decision has the dynamics of diversity, then voting is an efficient effort that can be done. However, minorities' interest still have to be protected through a critical response to the issues which are hindering themselves.
This principle basically prioritizes public legitimacy to a political decision. Minority groups such as Muslims in Tolikara should get a place for the government to their aspirations. Thus, the Tolikara policy is not only in favor of the majority alone. With the policy resulted collectively, a more legitimate outcome is expected by all parties, and it will certainly reduce the potential violence between majority and minority. Therefore, principles number 4 and 5 have a complementary relationship, namely the existence of an agreement resulting in a participatory manner to accommodate the interests of various parties.

6. Inclusiveness and solidarity: This principle emphasizes the urgency of the participation of the public to access public policies in order to keep the solidarity and the principle of inclusiveness. Inclusiveness is an important point that should be underlined in this principle. A policy is not only related to anyone who can propose, but must also be able to pick up the proposal. Like for example, poor people of Kampung Pulo. So far, solidarity and social relations that occur in their territory are never considered by the government as policy considerations. As a result, when there is a policy on spatial planning, then the existence of relationships and solidarity of them are not acknowledged. This is where the importance of inclusiveness policy takes place, that the government must provide access to pick up and take in-depth notice of the problems in the region. Solidarity then is given meaning that the creation of an inclusiveness allows their relationship to appreciate each other in the absence of a limitation.

7. The advance of serious harm: The availability of limited resources, making all policies should be concerned with priorities. One of the examples is the case in Rembang and Urut Sewu. The government's failure to perform articulation of the policy priorities the sources of violence. Natural resources is a potential to be exploited, but its presence has limitations. Therefore, the policy must be concerned with a priority. Then, if giving importance to priorities can abort the participation process? Of course not, because in determining policy priorities should be through participation stage by putting all the interest groups. So everything that will be produced can a consensus for all.

8. Sustainability: That is an attempt to think about the actions of the pro-environment in the future. Unfortunately, most governments and people in the area do not have enough awareness about the importance of environmental sustainability. Although in its history, the 
people of Indonesia have a good interaction in the utilization of natural resources. However, neo-liberalisation climate that encourages individuals to seek profit through great effort makes these interactions collapsed. Now, the government and the private sector, in particular, tend to have the exploitative will of towards the potential of natural resources. As in Rembang, the government in cooperation with the private sector to take risks for the sake of violence against farmers exploiting the mines of cement raw materials.

Of the eight expression by Held, there is the fact that the violence in the area is due to a gap in the democratic system that is used today. Through the application of the principles of cosmopolitan democracy, at least allow for the violence to no longer occur in the area. Therefore, violence as a common issue of each area should be a serious awareness on the importance of efforts to reflect the concept and application of democracy.

During this time, the violence continues in the area caused by the perpetrator who feels as the most correct and assumes another group is wrong. The actors also should reflect on themselves for any action to be taken in public space. The actors will then understand the consequences that must be obtained from any actions they did. Entanglement between the problem of violence to other areas should be a common issue in a global context that transcends geographic boundaries.

Through this effort, basically, the settlement can be done by identifying the fundamental issue about why humans can commit violence in the area. Hopefully, through global connections, addressing diverse issues can take the universality of the problem of violence, to provide answers to the problems of violence that occurred during the time in different parts of any region.

Community participation is reiterated as the giver input and control over policy. Through participation, the public can access the course of authority. Thus, through this control, the government is expected to no longer arbitrarily carry out a policy against its citizens.

Furthermore, the limited availability of resources, on the one hand, create social problems on a global level that is increasingly complex, while on the other hand, poverty and well-being are yet to be present evenly. Therefore, local communities must play an active role to take priority in accessing resources and minimize activities that have an impact on the environment. This becomes important because of limited resources can also lead to the potential birth of violence caused by the seizure of resource utilization.

\section{Regional Potential in Applying Cosmopolitan Democracy}

As Arendt analysis, the perpetrators who do not think make them not feel guilty in committing a crime. Therefore, in order to realize the mindset of the society or the human self, Arendt suggests greater political action in the public sphere through speech and action. The process of access to the public space of Arendt is in line with the ideals of cosmopolitan democracy.

Both Arendt and cosmopolitan democracy thinkers agree on the existence of human life that respects the existence of other human beings. Arendt says that when human conducts a political action in the public sphere, then there is the human identity disclosure. Cosmopolitan democracy also continues to seek to awaken people as part of the world, without limited by constraints of various identities. However, Arendt analyzes of acts of violence over the incident that occurred in the Nazi regime in Germany. Meanwhile, cosmopolitan democracy comes from globalization ongoing situation that blurs the boundary.

The regions in Indonesia have the potential to carry a cosmopolitan democracy. Here are four arguments regarding potential cosmopolitan democracy for regions in Indonesia. First: Start growing awareness of the public to choose the leader of capacity or quality, becoming a point for the quality of democracy in the region, although only some regions start to do this. It can be seen on the phenomenon of Muhammad Anton election as mayor of Malang, Joko Widodo as Jakarta Governor, and Basuki Tjahya Purnama as Jakarta Governor (substitute for Jokowi). Muhammad Anton as mayor of Malang is a citizen of ethnic Chinese descent. Meanwhile, Joko Widodo was mayor from Solo who later ran for governor of Jakarta. Basuki Tjahya, which initially became Deputy Governor of Jokowi then replaced him as governor, is a citizen of ethnic Chinese descent. The election of Anton and Jokowi are examples where communities have realized that by no longer giving special attention to regional leaders who should reproduce a native of the area or the ethnicity of the majority interest in the area. This awareness is part of the desired substance by the cosmopolitan democracy for the public awareness that transcends their ethnic territory and to obtain quality leader and not just focuses on native and son of ethnic descent. Although in some regions it can not be denied the phenomenon of people who want a leader that is a native son of the region is also still common. Hopefully, through leadership in the areas of quality, may be able to overcome the problem of violent conflict among community groups, or also can minimize the occurrence of violence caused by the government. Despite what has been done by Basuki some time ago which caused criticism for 
his actions that allow violence against residents of Kampung Pulo. But the main emphasis in this supposition is the public awareness to choose a quality leader.

Second: Connections of a social movement. The collapse of authoritarianism building of new order has brought the spirit of the community to form a community of civil society movements called NGO (NonGovermental Organizations). Currently, several NGOs in the regions have a network with similar organizations in other regions or in other parts of the world. This raises the potential for dialogue among communities that transcend regional boundaries to address the problems that occurred in each region. For example, a group of NGOs on behalf of prodemocracy, environment, anti-violence and anticorruption, usually have networks among regions and even to other countries. This connection is the part desired by cosmopolitan democracy. Where cosmopolitan democracy wants the discussion of common issues that go beyond the boundaries of the grassroots level group to look for the universality of the various problems that occur.

Third: Government Network, the network patterns of cooperation among government organizations today allow for the occurrence of cosmopolitan democracy. Jakarta, Bandung, and Surabaya are three regions that have often established cooperation between local authorities and foreign government. Their aim is to overcome the problems in their respective region to carry out the comparison study process with other regions that have similar issues and have been considered successfully overcome the problem. Indirectly, the three local governments have run priority of cosmopolitan democracy as expressed above by Archibugi. The fabrication of this cooperation process is also expected to discuss issues related to violence and human rights.

Fourth: The values of the locality are notentirely to be viewed poorly. Quite a few locality values in traditional society have taught a cosmopolitan life in advance of the arrival of the concept of cosmopolitanism of the West. For example, the tradition of preserving nature is a doctrine that has long been taught by Javanese society's norms. Likewise on respect for diversity. Indonesia has long taught society views to live together in unity, embodied in the term Unity in Diversity as a slogan.

The four points ar the argument of the potential application of cosmopolitan democracy in the region as an effort to cope with the violence that constantly occur. However, some of the barriers become the hindrance to the actualization of cosmopolitan democracy in regions such as religious fundamentalism, government's violence reason to discipline society, and low participation.

\section{Conclusion}

Through the formulation of the problem and research objectives, the following is the conclusion of the study. Th conclusions is also obtained after the discussion of the facts of violence in the regions and explain the concept of cosmopolitan democracy, with conclusions as follows:

1. That the violence occurred is due to the lackmindedness of perpetrators of violence in the regions. The perpetrators do not realize that the act of doing a crime has the potential for renewed violence sparked.

2. The process of access to the public space by Arendt is in line with the ideals of cosmopolitan democracy. Both Arendt and cosmopolitan democracy thinkers agree on the existence of human life that respects the existence of other human beings. Arendt said that when human conduct a political action in the public sphere, then there is the human identity disclosure. Cosmopolitan democracy also continues to seek to awaken people as part of the world, without restricted by region borders (country), ethnic, and religion and belief. However, cosmopolitan democracy does not intend to abolish the state by establishing a world state.

3. To minimize the occurrence of violence, then society and governments in the region should recognize the potential for cosmopolitanism in the region. Such as Awareness for selecting quality leaders, social movement organizations connection, Network Government and understand the values of the locality which contain elements of cosmopolitanism. Society and the government should also be aware of the dangers of religious fundamentalism, violence reason used by the government to discipline the society, and the lack of participation, as the barriers to the implementation of cosmopolitan democracy in the region.

\section{Suggestion/Recommendation}

The recommendations below are the result of reflection towards the discussion conducted, as follows:

4. The need for public, government, and private awareness, in the regions of diverse life, and always consider the action to be performed. The thinking process is one way to minimize the likelihood of violence of action.

5. The participation of the public to access public spaces. With this, the community is expected to unmask their identity and able to control the existing power structure.

6. The need for government's attention in its efforts to examine the failure of democracy in Indonesia. The government should be aware that during this time, the violence in the 
region is the proof that democracy has failed to be applied substantially. This assessment is expected to update the concept of democracy that is more humane to be applied in the regions.

\section{REFERENCES}

Adian, D. (2010). Kekeliruan Politik Multikultural Kita. Jurnal Maarif Institute, 5(2), 12-25.

Anam, K. (2013). Tahun 2013, Pelanggaran HAM di Indonesia Meningkat. Tempo. Retrieved 24 March 2016, from https://m.tempo.co/read/ news/2013/12/26/078540272/tahun-2013pelanggaran-ham-di-indonesia-meningkat

Andrianto, A. (2015). Kronologi Bentrok TNI dan Petani Urut Sewu / Tempo Nasional. Tempo Nasional. Retrieved 13 September 2015, from http://nasional.tempo.co/read/ news/2015/08/22/058694176/kronologibentrok-tni-dan-petani-urut-sewu

Apriando, T. \& Saturi, S. (2014). Tolak Tambang dan Pabrik Semen, Warga Rembang Diintimidasi TNI/Polri / Mongabay.co.id. Mongabay.co.id. Retrieved 13 September 2015, from http:// www.mongabay.co.id/2014/06/16/tolaktambang-dan-pabrik-semen-warga-rembangdiintimidasi-tnipolri/

Archibugi, D. (2008). The Global Commonwealth of Citizens. Princeton: Princeton University Press.

Arendt, H. (2012). Eichmann in Jerusalem : Reportase Tentang Banalitas Kejahatan. Yogyakarta: Pustaka Pelajar.

Badan Pusat Statistik. (2015). Bps.go.id. Retrieved 24 April 2016, from http://bps.go.id/brs/ view/1158/

Beck, U. \& Cronin, C. (2006). The Cosmopolitan Vision. Cambridge, UK: Polity Press.

Cosmopolitan Democracy Definition / Define Cosmopolitan Democracy. Governmentvs.com. Retrieved 14 September 2015, from http:// www.governmentvs.com/en/cosmopolitandemocracy-definition/model-84-11

Dwicipta., \& Ardianto, H. (2015). \#Rembang melawan. Yogyakarta: Ladang Kata ; Literasi Press.

Ginting, K. (2015). Penggusuran Paksa Kampung Pulo Disebut sebagai Kediktatoran Ahok monitorday.com. MONITORDAY.com. Retrieved 13 September 2015, from http://www. monitorday.com/detail/12516/penggusuranpaksa-kampung-pulo-disebut-sebagaikediktatoran-ahok

Habibullah, M. (2012). Universalisme dan
Kosmopolitanisme dalam Budaya Islam: Sebuah Analisis Normatif dan Historis. Tajdid, 11(1).

Haryatmoko,. (2014). Etika Politik dan Kebudayaan. Jakarta: Kompas.

Held, D. (1995). Democracy and the Global Order. Cambridge, UK: Polity Press.

Held, D. (2005). Philosophy of Cosmopolitanism. Cambrige, UK: Cambridge University Press.

Juvenal, S. (2016). Diogenes. Penelope.uchicago. edu. Retrieved 14 September 2015, from http://penelope.uchicago.edu/ grout/ encyclopaedia_romana/greece/hetairai/ diogenes.html

Kaldor, M. (2000). Cosmopolitanism and Organised Violence. Presentation, Warwick.

Karib, F. (2016). Kekerasan dan Gagalnya Demokrasi Kita : Tanggapan Untuk Philips Vermonte. Jakartabeat.net. Retrieved 13 September 2015, from http://www.jakartabeat.net/ kolom/konten/kekerasan-dan-gagalnyademokrasi-kita-tanggapan-untuk-philipsvermonte?lang=id

Kuyper, J. (2012). The Limits of Design for Cosmopolitan Democracy. Public Reason, 4(12), 28-47.

Mardalis,. (2002). Metode Penelitian: Suatu Pendekatan Proposal. Jakarta: Bumi Aksara.

Paskalis, Y. (2016). Kapolda Tito: 800 Polisi dan TNI Siaga di Kalijodo. Tempo. Retrieved 21 March 2016, from https://m.tempo.co/read/ news/2016/02/26/064748503/kapolda-tito800-polisi-dan-tni-siaga-di-kalijodo

Priyono, A. \& Hamid, U. (2014). Merancang Arah Baru Demokrasi. Jakarta: Gramedia.

Snyder, J. (2003). Dari Pemungutan Suara ke Pertumpahan Darah: Demokratisasi dan Konflik Nasionalis. Jakarta: KPG.

Syeirazi, M. (2003). Dilema Praktis Globalisme Neoliberal. Jurnal Ilmu Sosial Dan Ilmu Politik UGM, 7(1), 1-34.

The Wahid Institute,. (2014). Laporan Tahunan Kebebasan Beragama/ Berkeyakinan dan Intoleransi. Jakarta: The Wahid Institute.

Wattimena, R. (2011). Hannah Arendt, Banalitas Kejahatan, dan Situasi Indonesia. Rumah Filsafat. Retrieved 13 September 2015, from https://rumahfilsafat.com/2011/12/26/ hannah-arendt-banalitas-kejahatan-dansituasi-indonesia/

Winarno, B. (2008). Globalisasi dan Masa Depan Demokrasi. Jurnal Global Dan Strategis, 3(2), 123-141. 